\title{
Perceraian dan Akibat Hukumnya terhadap Anak dan Harta Bersama Menurut Hukum Adat Osing di Desa Aliyan, Kecamatan Rogojampi, Kabupaten Banyuwangi
}

\author{
Muhamad Jefri Ananta \\ University of Jember, Indonesia \\ Jefri.anant@yahoo.co.id \\ Dominikus Rato \\ University of Jember, Indonesia \\ dominikusrato@gmail.com \\ I Wayan Yasa \\ University of Jember, Indonesia \\ wayanyasash@gmail.com
}

\begin{abstract}
Divorce or dissolution of the marriage means the return of husband and wife into group family own. According to Osing adat law in Aliyan village, Rogojampi, Banyuwangi Regency, the divorce will give the rise to rights and obligations of children and joint property. The community of Osing adat law embraces the system of bilateral kinship which pulls the descendant line of the second parent with regard to the divorce by which children are given the freedom to choose by following the father or the mother. The community of Osing adat law never discriminates on the ground of biological children, legal children, adopted children and stepchildren, and legal position children. In the system of bilateral kinship, with regard to the divorce, the legal position of the property will return to the origin and joint property will be shared equally.
\end{abstract}

KEYWORDS: Divorce, Osing Adat Law, Legal Position, Children, Joint Property.

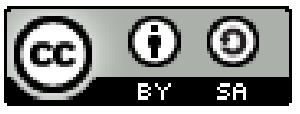

Copyright $\odot 2017$ by Author(s)

This work is licensed under a Creative Commons Attribution-ShareAlike 4.0 International License. All writings published in this journal are personal views of the authors and do not represent the views of this journal and the author's affiliated institutions.

\section{HOW TO CITE:}

Ananta, Muhamad Jefri, Dominikus Rato \& I Wayan Yasa. "Perceraian dan Akibat Hukumnya terhadap Anak dan Harta Bersama Menurut Hukum Adat Osing di Desa Aliyan" (2017) 4:3 Lentera Hukum 229-244.

Submitted: October 18, 2017 Revised: September 22, 2017 Accepted: December 19, 2017 


\section{PERCERAIAN DAN AKIBAT HUKUM MENURUT HUKUM ADAT OSING}

Indonesia adalah negara kesatuan yang penuh dengan keaneragaman budaya, ras, suku, agama dan kepercayaan. Indonesia mampu mempersatukan berbagai keragaman itu sesuai dengan semboyan bangsa Indonesia Bhinneka Tuggal Ika, yang berarti berbedabeda tetapi tetap satu jua. Keaneragaman budaya, ras, suku, agama dan kepercayaan yang ada di Indonesia maka muncullah pluralisme hukum. ${ }^{1}$ Indonesia sendiri menganut tiga sistem hukum yaitu hukum adat, hukum islam, hukum barat, ketiga hukum tersebut saling berkesinambungan antara yang satu dengan yang lain. Hukum adat adalah hukum yang berlaku secara normatif dalam suatu masyarakat hukum adat. ${ }^{2}$ Dalam pikiran masyarakat adat, hukum adalah sesuatu yang biasa dan dipahami secara biasa yang wajib ditaati, tidak perlu dihindari, tetapi perlu dilakukan rekontruksi dan bila perlu diproduksi. ${ }^{3}$

Salah satu desa yang masih menjunjung perilaku adatnya dan masih mempertahankan adat-istiadat Osing adalah di Desa Aliyan, Kecamatan Rogojampi, Kabupaten Banyuwangi. Nama Desa Aliyan diambil dari corak kehidupan masyarakat pada jaman Hindia Belanda, dimana masyarakat sering berpidah-pindah dari suatu tempat ketempat lainnya untuk menghindari kekejaman para penjajah. Masyarakat yang berpindah-pindah ini akhirnya berkumpul menjadi satu dan membentuk sebuah desa yang diberi nama Desa Aliyan. Nama "Aliyan" berasal dari kata "alih" atau menurut bahasa Osing "ngalih" yang artinya "berpindah-pindah". Karakteristik masyarakat Desa Aliyan adalah masyarakat heterogen yaitu masyarakat pendatang yang berasal dari berbagai latar belakang yang lama kelamaan menjadi satu ragam budaya masyarakat Banyuwangi asli yaitu masyarakat Osing.

Kelangsungan hidup suatu masyarakat dijamin dalam perkawinan. Secara teoritis hukum perkawinan merupakan bagian dari hukum keluarga. Namun, dalam hal pengkajian hukum perkawinan dapat berdiri sendiri. Apalagi hukum adat yang memang secara substantif saling berkaitan satu sama lain. Perkawinan dan keluarga menurut hukum adat memiliki hubungan yang sangat kuat, bukan semata-mata hanya hubungan seorang laki-laki dan seorang perempuan, melainkan perkawinan adalah implementasi perintah Tuhan yang melembaga dalam masyarakat untuk membentuk rumah tangga dalam ikatan keluarga. ${ }^{5}$ Perkawinan menurut Hukum Adat Osing di Banyuwangi memiliki makna yang dipedomani sebagai kosmologi yaitu pandangan manusia terhadap alam semesta, di mana alam dijadikan sebagai objek hukum

Sulistyowati Irianto, Pluralisme Hukum Waris dan Keadilan Perempuan / Sulistyowati Irianto (Jakarta: Yayasan Pustaka Obor Indonesia, 2016) hlm. 5.

2 Dominikus Rato, Hukum Perkawinand dan Waris Adat: Sistem Kekerabatan, Bentuk Perkawinan dan Pola Pewarisan Adat Di Indonesia (Surabaya: Laksbang Yustisia Surabaya, 2011) hlm. 2.

Ibid.

4 Sarifudin, Hasil wawancara dengan Bapak Sarifudin sebagai Tokoh Masyarakat Desa Aliyan, Kecamatan Rogojampi, Kabupaten Banyuwangi (2017).

5 Otje Salman, Rekonseptualisasi hukum adat kontemporer: telaah kritis terhadap hukum adat sebagai hukum yang hidup dalam masyarakat, Telaah kritis terhadap hukum adat sebagai hukum yang hidup dalam masyarakat (Bandung: Alumni, 2002) hlm. 173. 
(makrokosmis) dan manusia dijadikan sebagai subjek hukum (mikrokosmos). Masyarakat Adat Osing menganggap perkawinan memiliki 4 (empat) makna yaitu makna religius, makna ekonomis, makna sosial dan makna hukum. ${ }^{6}$ Secara antropologis, perkawinan merupakan bagian dari lingkaran hidup manusia, cakranggilingan. Secara sosiologis, perkawinan merupakan sebuah fenomena sosial yang mengubah status hukum seseorang. Status hukum setelah terjadinya perkawinan mengubah status perjaka atau gadis yang belum dewasa menuju sebuah tahap sosial dengan status hukum yang baru yaitu suami bagi laki-laki dan isteri bagi perempuan. Status suami dan isteri ini terus mengalami perubahan ketika keduanya mempunyai anak, sehingga keduanya dipanggil ayah bagi suami dani ibu bagi isteri. ${ }^{7}$ Pada umumnya keluarga dan persekutuan menghendaki langgengnya sebuah perkawinan. Namun realitanya tidak semua perkawinan dapat langgeng untuk selamanya, ada situasi dan kondisi yang menyebabkan terputusnya perkawinan seperti kepentingan keluarga atau persekutuan dan adanya persoalan pribadi sebagai alasan untuk bercerai.

Hakikat perceraian adalah ketika tidak ditemukan lagi keharmonisan dalam perkawinan. Undang-Undang Nomor 1 Tahun 1974 tentang Perkawinan (Lembaran Negara Tahun 1974 Nomor 1, Tambahan Lembaran Negara Nomor 3019) menentukan bahwa perceraian merupakan salah satu sebab dari putusnya perkawinan, disamping sebab lain yakni kematian dan putusan pengadilan. Mempertegas peraturan tersebut Subekti menjelaskan perceraian ialah penghapusan perkawinan karena keputusan hakim atau tuntutan salah satu pihak dalam perkawinan. ${ }^{8}$ Perceraian menurut hukum adat Osing adalah peristiwa luar biasa yang merupakan problem sosial yuridis, dimana dalam sebuah tertib hukum menurut garis keturunan bapak atau garis keturunan ibu, sebuah pembubaran perkawinan mas-kawin mengandung arti kembalinya sang suami dan isteri tersebut kedalam kelompok kekerabatannya sendiri.

Alasan terjadinya perceraian itu sangatlah bervariasi. Pada umumnya alasan terjadinya perceraian adalah karena adanya perzinahan yang dilakukan oleh pihak suami maupun pihak isteri. Alasan lain adalah tidak mendapatkan keturunan, karena kerukunan rumah tangga yang tidak dapat dipertahankan lagi, dan karena adanya campur tangan mertua. ${ }^{9}$ Dalam hal Perceraian Banyuwangi menduduki peringkat kedua ditingat Jawa Timur dan peringkat ketiga di tingkat Nasional. Hal ini menunjukkan bahwa di wilayah ini perceraian cukup memprihatinkan. Padahal masyarakat adat Osing di Banyuwangi menganggap perceraian sebagai pelanggaran, karena perceraian adalah suatu hal yang tidak disukai dan dibenci. Cita-cita masyarakat adat Osing mengenai perjodohan adalah untuk seumur hidup. Masyarakat Osing sangat membenci perceraian, karena akan menimbulkan masalah baru terhadap

\footnotetext{
6 Nur Ainiyah, "View of ISLAM, OSING DALAM BINGKAI TRADISI DAN KOSMOLOGI: Studi Nelayan Kedungrejo-Banyuwangi”, online: 〈http://ejournal.kopertais4.or.id/tapalkuda/index.php/ lisan/article/view/2841/2095> hlm. 217.

Rato, supra note 2 hlm. 4.

Subekti, Pokok-pokok hukum perdata (P.T. Intermasa, 1978) hlm. 42.

9 Bambang Daru Nugroho, Asas-asas e tatanan hukum adat (Mandar Maju, 201l) hlm. 153.
} 
anak dan harta bersama (gono-gini). Maka dari itu penulis tertarik untuk meneliti dan mengkaji permasalahan tersebut.

\section{AKIBAT HUKUM DARI PERCERAIAN TERHADAP ANAK DAN HARTA BERSAMA MENURUT HUKUM ADAT OSING DI DESA ALIYAN, BANYUWANGI}

Akibat hukum timbul sebab adanya hubungan hukum, ${ }^{10}$ misalnya perkawinan antara seorang laki-laki (suami) dan seorang perempuan (isteri) itu merupakan hubungan hukum yang memberikan hak-hak dan kewajiban kepada kedua belah pihak. Akibat hukum juga diartikan sebagai akibat yang diberikan oleh hukum atas suatu tindakan subyek hukum. Tidak hanya sebuah pernikahan yang akan menimbulkan akibat hukum, tetapi putusnya perkawinanpun akan menimbulkan akibat hukum, baik putusnya perkawinan karena kematian, perceraian dan putusan pengadilan. ${ }^{11}$

Setelah terjadi putusnya perkawinan karena perceraian, sudah dapat dipastikan akan menimbulkan akibat hukum terhadap para pihak yang melakukan perceraian. Akibat hukum dari perceraian ini tentunya akan menyangkut terhadap anak dan harta kekayaan selama perkawinan berlangsung (harta bersama). Anak dan harta bersama biasanya akan menjadi sengketa oleh suami isteri yang ingin melakukan percerain. Pengadilan harus berperan dalam proses penyelesaian persengketaan anak dan harta bersama antara para pihak yang ingin melakukan perceraian. Pengadilan juga akan menjadi media bagi suami isteri yang bersengketa untuk menuangkan semua argumentasi mereka, khususnya untuk menengahi dan mecari jalan keluar supaya memperoleh keadilan dan tidak merugikan kedua belah pihak. Menurut masyarakat Osing di Desa Aliyan, Kecamatan Rogojampi, Kabupaten Banyuwangi, putusnya suatu perkawinan karena perceraian akan berakibat hukum terhadap anak dan harta bersama.

\section{A. Terhadap Anak}

Anak merupakan hubungan kekeluargaan berdasarkan hubungan darah baik melalui perkawinan yang sah maupun melalui perkawinan yang tidak sah, seperti anak luar kawin dan anak hasil zina. ${ }^{12}$ Anak yang sah anak yang di lahirkan dari suatu perkawinan yang sah, sedangkan anak luar kawin adalah anak yang dilahirkan tanpa adanya suatu perkawinan yang sah yang hanya memiliki hubungan perdata dengan ibunya. Menurut Sri Susilowati Mahdi manusia memiliki status sebagai subjek hukum sejak ia dilahirkan, anak yang masih dalam kandungan dapat menjadi subjek hukum apabila ada kepentingan yang menghendaki dan dilahirkan dalam keadaan hidup. ${ }^{13}$

10 J.C.T. Simorangkir, Kamus hukum: oleh J. C. T. Simorangkir, Rudy T. Erwin dan J. T. Prasetyo (Madjapahit, 1972) hlm. 6.

$11 \quad$ Ibid.

12 Rato, supra note $2 \mathrm{hlm} .138$.

13 Sulistyowati Mahdi \& dkk, Hukum Perdata: Suatu Pengantar (Jakarta: Gitama Jaya Jakarta, 2005) hlm. 21. 
Anak merupakan seseorang yang belum berusia 18 (delapan belas) tahun ${ }^{14}$, termasuk anak yang masih dalam kandungan yang selalu menjadi bagian dari keluarga dan masyarakat. Hak seorang anak adalah memperoleh kasih sayang, perlidungan serta pendidikan dari orang tua. Perceraian merupakan hal yang akan menimbulkan kesengsaraan atau penderitaan secara psikis seorang anak yang akan berdampak buruk bagi pertumbuhan dan perkembangannya, sehingga anak merupakan pihak yang paling menderita dengan terjadinya perceraian orang tuanya.

Pada masyarakat patrilineal yang melakukan perkawinan jujur (perkawianan dengan pembayaran mas kawin), apabila terjadi pembubaran perkawinan karena kematian atau karena perceraian maka kedudukan anak tetap berada dalam kekerabatan suami, dan yang bertanggung jawab atas semua biaya pemeliharaan dan pendidikan anak adalah bapak kandungnya atau semua kerabat laki-laki dari bapak kandungnya. ${ }^{15} \mathrm{Hal}$ ini berbeda pada masyarakat matrilineal, apabila terjadi perceraian maka anak berkedudukan dalam kekerabatan isteri. Seorang anak bisa ikut bersama bapaknya, jika perkawinan bapak dan ibunya semula berbentuk semenda. Tetapi pada dasarnya anak tetap berkedudukan di pihak ibu dan kerabat ibunya. ${ }^{16}$

Masyarakat Adat Osing menganut sistem kekerabatan parental atau bilateral yaitu menarik garis keturunan dari kedua belah pihak orang tua, yaitu bisa ditarik dari garis keturunan bapak maupun ditarik dari garis keturunan ibu. Dalam sistem kekerabatan parental atau bilateral, apabila terjadi perceraian maka kedudukan seorang anak tergantung pada keadaan, biasanya anak yang sudah dewasa di babaskan memilih ikut dengan bapak atau ibunya. Di Desa Aliyan, Kecamatan Rogojampi, Kabupaten Banyuwangi, akibat hukum yang ditimbulkan dari perceraian terhadap anak pada masyarakat Osing di desa Aliyan adalah anak tetap berhak mendapatkan kasih sayang dari kedua orang tuanya yang bercerai. ${ }^{17}$ Kedua orang tua yang sudah bercerai tetap berkewajiban memelihara dan mendidik anak-anaknya. Bapak bertanggung jawab atas semua biaya pemeliharaan dan pendidikan yang diperlukan oleh anak. Apabila bapak dalam kenyataannya tidak mampu memenuhi kewajiban membiayai pemeliharaan dan pendidikan anak, maka ibu ikut memikul biaya untuk pemeliharaan dan pendidikan anak. ${ }^{18}$

Posisi anak bagi orang tua adalah "gantelane ati", ${ }^{19}$ yang artinya anak sebagai gantungannya hati maksudnya anak adalah darah daging sendiri yang harus dijaga dan dipelihara dengan baik karena anak sebagai penerus orang tuanya dan anak akan merawat orang tuanya kelak apabila orang tua sudah tua. Oleh karena itu perasaan orang tua terhadap anak dijelaskan dalam ungkapan "welase emak nang anak sengono watese"

14 Undang-undang No.23 Tahun 2002 Tentang Perlindungan Anak (VisiMedia) hlm. 4.

15 Hilman Hadikusuma (Haji), Hukum perkawinan adat (Citra Aditya Bakti, 2003) hlm. 139.

16 Ibid.

17 Paturi, Hasil wawancara dengan Bapak Paturi sebagai Sekretaris Desa Aliyan, Kecamatan Rogojampi, Kabupaten Banyuwangi (2017).

18 Ibid.

19 Lisudalmi, Hasil wawancara dengan Ibu Lisudalmi sebagai Warga desa Aliyan yang pernah melakukan perceraian (2017). 
artinya kasih sayang seorang ibu terhadap anak tidak ada batasnya maksudnya meskipun terjadi perceraian seorang ibu akan merawat anaknya dengan baik meskipun harus banting tulang untuk membiyai pendidikan dan pemeliharan anak. Biasanya seorang bapak "mungkur sedot" artinya tidak bertanggung jawab setelah terjadi perceraian. Seorang bapak tidak ikut membiayai pemeliharaan dan pendidikan seorang anak. ${ }^{20}$

Terkait dari uraian diatas, akibat hukum dari perceraian terhadap anak di Desa Aliyan, Kecamatan, Rogojampi, Kabupaten Banyuwangi, sudah jelas bahwa meskipun suatu perkawinan sudah putus karena perceraian, tidaklah mengakibatkan hubungan antara orang tua dan anak-anak yang lahir dari perkawinan tersebut menjadi putus, namun tetap melekat hak seorang anak untuk memperoleh perlindungan dan kasih sayang dari orang tuanya. Orang tua berkewajiban membiayai, memelihara dan mendidik anak-anaknya. Bapak bertanggung jawab atas semua biaya pemeliharaan dan pendidikan yang diperlukan oleh anak. Akibat lain yang ditimbulkan dari perceraian yaitu mengenai hak asuh anak, dimana anak yang belum dewasa yang masih berumur dibawah 12 tahun menjadi hak ibunya, sedangkan apabila anak sudah dewasa berumur diatas 12 tahun anak dibebaskan untuk memilih diantara ayah atau ibunya sebagai pemegang hak asuh dan semua biaya pemeliharaan ditanggung oleh ayahnya. Meskipun kenyataan menunjukkan bahwa hanya ibu yang menanggung biaya pengasuhan dan pemelihataan anak. $^{21}$

\section{B. Terhadap Harta}

Putusnya suatu perkawinan karena sebab kematian salah satu pihak, perceraian ataupun atas putusan pengadilan akan menimbulkan suatu akibat hukum terhadap harta perkawinan. Oleh karenanya perlu adanya penentuan kepemilikan harta selama dalam hubungan perkawinan. Dalam hal perceraian dapat segera ditentukan mengenai harta bawaan yang menjadi hak seorang isteri dan harta bawaan yang menjadi hak suami, supaya mudah menentukan mengenai harta yang dapat dibagi yaitu mengenai harta bersama (harta gono gini). Pada umumnya harta perkawinan itu cukup digolongkan atas dua bagian yaitu sebagian berasal dari kekayaan suami dan isteri masing-masing terpisah satu dari yang lain dan sebagian lagi merupakan cumpur kaya yaitu harta bersama atau sering disebut harta gono-gini. ${ }^{22}$

Dari segi tingkatan harta terdiri atas harta pusaka tinggi dan harta pusaka rendah. ${ }^{23}$ Harta pusaka tinggi adalah harta yang diwaris tinggi, atau lebih dikenal dengan harta asal. Sebaliknya harta pusaka rendah dikenal sebagai harta gono gini (sisa konsumsi atau hasil menabung), hasil keringat, dan hasil kerja bersama antara suami isteri selama perkawinan berlangsung. Menurut Dominikus Rato harta gono gini adalah sebuah konsep atau pengertian yang diberikan kepada sejenis benda materiil

\footnotetext{
20 Ibid.

21 Hasil wawancara dan kesaksian Bapak Ishak Maulana, Ibu Lisudalmi dan Ibu Suwati (2017).

22 Wirjono Prodjodikoro, Hukum perkawinan di Indonesia (Sumur Bandung, 1966) hlm. 72.

23 Rato, supra note 2 hlm. 74.
} 
baik tanah maupun bukan tanah, seperti hewan, hasil kebun, yang dihasilkan oleh sepasang suami isteri selama dalam ikatan perkawinan. ${ }^{24}$

Hasil keringat adalah sebuah konsep atau pengertian yang pada umumnya diberikan kepada suatu benda baik tanah maupun bukan tanah yang dihasilkan dari tanah, misalnya dibeli dengan padi, jagung, kopi atau uang yang dihasilkan dari hasil bumi, oleh perorangan (Minang, kerbau: harta pembujangan tau harta penantian). Hasil kerja sediri adalah sebuah konsep atau pengertian yang diberikan kepada suatu benda yang bukan tanah dan dihasilkan oleh perorangan misalnya karena berdagang, buruh dan sebagai pegawai. ${ }^{25}$ Harta hasil keringat, harta bawaan dan harta gono-gini ini di pisahkan untuk mempermudah pembagian harta ketika terjadi perceraian.

Harta perkawinan merupakan harta yang dikuasai suami isteri selama mereka terikat dalam ikatan perkawinan baik harta yang berasal dari warisan, harta hibah, harta penghasilan sendiri dan harta penghasilan bersama. Semua harta tersebut dipengaruhi oleh sistem kekerabatan yang dianut, seperti sistem kekerabatan patrilineal, matrilineal dan bilateral atau parental. Pada masyarakat adat yang menganut sistem kekerabatan patrilineal dengan bentuk perkawinan pembayaran jujur, kedudukan isteri harus tunduk pada aturan kekerabatan suami. Pada umumnya semua harta perkawinan dikuasai oleh suami sebagai kepala rumah tangga/keluarga. Apabila terjadi perceraian dan isteri meninggalkan tempat kedudukan suaminya, berarti isteri melanggar adat, maka isteri tidak berhak menuntut bagian dari harta bersama ataupun terhadap harta bawaannya. Sedangkan pada masyarakat yang menganut sistem kekerabatan matrilineal yang bentuk perkawinannya semenda, apabila terjadi perceraian maka yang berhak atas harta perkawinan adalah isteri dan kerabat isteri, jika suami isteri bermata pencaharian berimbang maka dibagi bersama. ${ }^{26}$

Di Desa Aliyan, Kecamatan Rogojampi, Kabupaten Banyuwangi, akibat hukum yang ditimbulkan dari perceraian terhadap harta bersama adalah timbulnya hak suami isteri terhadap harta yang dihasilkan selama hubungan perkawinan berlangsung, dimana harta bersama "disigar prak" ${ }^{27}$ artinya harta bersama dibagi sama rata. Pembagian harta bersama tidak dilihat dari prestasi pihak yang bekerja keras, melainkan didasarkan pada hidup bersama selama perkawinan. Meskipun seorang isteri tidak bekerja namun loyalitas seorang isteri seperti taat pada suami, mengurus anak dan mengatur keuangan rumah tangga dengan baik maka seorang isteri mempunyai hak dan bagian yang sama dengan suami terhadap harta bersama selama perkawinan berlangsung. ${ }^{28}$

Pada setiap daerah masyarakat mengenal harta bersama dengan istilah yang berbeda-beda Di Jawa, harta bersama disebut dengan harta "gono gini", di Sunda disebut dengan harta "guna kaya", di Bugis harta "cakara", dan di Bajar disebut dengan harta

Ibid.

25 Ibid.

26 Hadikusuma (Haji), supra note $15 \mathrm{hlm} .140$.

27 Suwati, Hasil wawancara dengan Ibu Suwati sebagai masyarakat yang pernah melakukan perceraian di Desa Aliyan, Kecamatan Rogojampi, Kabupaten Banyuwangi (2017).

28 Ibid. 
"berpantangan". Meskipun berbeda istilah namun hakikatnya adalah sama, yaitu terletak pada harta benda milik suami isteri yang dibawa kedalam suatu pernikahan sehingga menjadi harta bersama. Sebagaimana penjelasan Andi Hamzah, harta bersama adalah harta yang diperoleh bersama suami isteri selama perkawinan berlangsung. ${ }^{29}$ Segala tindakan dan perbuatan hukum mengenai harta bersama akibat dari perceraian dapat disepakati dengan adanya musyawarah dan mufakat antara pihak keluarga suami dengan pihak keluarga isteri yang didampingi oleh tetua adat. Namun, di Desa Aliyan semua keputusan mengenai akibat hukum dari perceraian terhadap harta bersama dilakukan secara musyawarah dan mufakat para pihak keluarga yang didampingi oleh tokoh masyarakat bukan tetua adat. Sistem Pemerintahan Desa Aliyan dipimpin oleh Kepala Desa yang dibantu oleh Sekretaris Desa sehingga tidak ada tetua adat di desa Aliyan meskipun mayoritas masyarakat desa Aliyan adalah suku Osing. ${ }^{30}$ Masyarakat adat Osing menganut sistem kekerabatan parental atau bilateral dimana kedudukan suami isteri sejajar. Harta bersama dikuasai bersama dan untuk kepentingan bersama. Apabila terjadi perceraian maka kedudukan harta asal akan kembali ke asal sedangkan harta gono gini akan dibagi sama rata.

Berdasarkan uraian diatas akibat hukum dari perceraian terhadap harta bersama di desa Aliyan, suami atau isteri yang telah bercerai berhak atas harta bersama yang dihasilkan selama perkawinan berlangsung, tanpa melihat prestasi pihak mana yang bekerja keras. Pembagian harta bersama didasarkan pada hidup bersama selama perkawinan, meskipun seorang isteri tidak bekerja namun loyalitas seorang isteri seperti taat pada suami, mengurus anak dan mengatur keuangan rumah tangga dengan baik maka seorang isteri mempunyai hak dan bagian yang sama dengan suami terhadap harta bersama. Dalam pembagian harta bersama karena perceraian, ini dilakukan dengan cara musyawarah dan mufakat.

\section{STATUS HUKUM MASING-MASING ANAK DAN HARTA BENDA AKIBAT PERCERAIAN MENURUT HUKUM ADAT OSING DI DESA ALIYAN}

\section{A. Status Anak}

Anak adalah keturunan atau generasi sebagai suatu hasil dari hubungan seksual antara seorang laki-laki dengan seorang perempuan baik dalam ikatan perkawinan maupun diluar ikatan perkawinan. Sebagaimana penjelasan Dominikus Rato bahwa menurut masyarakat hukum adat dari suatu ikatan perkawinan tidak saja terdapat anak kandung, tetapi juga terdapat anak sah, anak angkat dan anak tiri. ${ }^{31}$ Anak dipandang sebagai wadah semua harapan dan pelindung orang tuanya kelak, apabila orang tua itu sudah tidak mampu lagi secara fisik untuk mencari nafkah.

\footnotetext{
29 Andi Hamzah, Kamus hukum, cet. l edition ed (Jakarta: Ghalia Indonesia, 1986) hlm. 232.

30 Paturi, supra note 17.

31 Rato, supra note $2 \mathrm{hlm}$. 142.
} 
Anak kandung, anak sah, anak angkat dan anak tiri ada sangkut pautnya dengan hak dan kewajiban orang tua yang mengurus atau memeliharanya, begitu pula sebaliknya. Kedudukan anak-anak tersebut pengaturannya juga berlatar belakang pada susunan masyarakat adat bersangkutan dan bentuk perkawinan orang tua yang berlaku. Bukan tidak menjadi masalah tentang sah tidaknya anak, hal mana dipengaruhi oleh agama yang dianut masyarakat bersangkutan, tetapi yang juga penting adalah menyangkut masalah keturunan.

Kedudukan anak bagi masyarakat adat dengan sistem kekerabatan patrilineal adalah sebagai penerusan keturunan menurut garis bapak. Sehingga ada kemungkinan keluarga yang tidak mempunyai anak laki-laki atau tidak mempunyai anak sama sekali, mengangkat anak lelaki orang lain menjadi penerus keturunan yang kedudukannya sejajar dengan anak sendiri. Berbeda dengan masyarakat dengan sistem kekerabatan matrilineal dimana kedudukan anak dikaitkan dengan penerusan keturunan menurut garis ibu. Sehingga ada kemungkinan keluarga yang tidak mempunyai anak wanita atau tidak mempunyai anak sama sekali mengangkat anak mengangkat anak perempuan orang lain untuk menjadi penerus keturunan yang berkedudukan sejajar dengan anak sendiri. ${ }^{32}$

Masyarakat adat Osing menganut sistem kekerabatan parental atau bilateral yaitu menarik garis keturunan dari kedua belah pihak orang tua, yaitu bisa ditarik dari garis keturuanan bapak maupun ditarik dari garis keturunan ibu. Sistem kekerabatan parental atau bilateral ini anak laki-laki dan anak perempuan sejajar kedudukannya. Di dalam masyarakat Osing terdapat macam-macam anak yaitu anak kandung, anak sah, anak angkat dan anak tiri. Dengan adanya perceraian maka akan menimbulkan akibat hukum terhadap macam-macam anak tersebut.

\section{Status anak kandung}

Di berbagai literatur, ketika membahas kedudukan anak kandung, harus dibaca terlebih dahulu mengenai anak sah. Anak kandung belum tentu anak sah. Menurut Dominikus Rato anak kandung adalah yang dilahirkan oleh ibunya, sebab seorang bapak tidak mungkin mengandung. ${ }^{33}$ Anak kandung hanya memiliki ikatan keperdataan dengan ibunya, karena anak kandung dilahirkan dari rahim ibunya tanpa pengakuan dari ayahnya.

Seorang bapak bisa saja tidak mengakui anak itu sebagai anaknya jika secara yuridis dapat dibuktikan bahwa anak itu tidak berasal dari sperma yang membuahinya. Anak kandung juga belum tentu anak sah, misalkan anak itu berasal dari anak zinah, hasil hubungan sexual dengan laki-laki lain yang bukan suaminya. Anak ini anak kandung bagi perempuan itu tetapi bukan anak sah. Anak kandung mempunyai hubungan hukum dengan ibunya atau lebih tegas lagi dikatakan bahwa anak tidak sah hanya mempunyai hubungan hukum dengan ibunya, karena dia lahir dari kandungan ibunya.

32 Hadikusuma (Haji), supra note $15 \mathrm{hlm} .139$.

33 Rato, supra note $2 \mathrm{hlm}$. 150. 
Menurut hukum adat akibat hukum yang ditimbulkan terhadap anak kandung dari perceraian yaitu anak kandung tetap ikut dengan ibunya, biaya pemeliharan dan pendidikan yang menanggung ibunya. Anak kandung hanya berhak atas harta benda ibunya, karena anak kandung memiliki ikatan keperdataan dengan ibunya. Anak kandung tidak memiliki ikatan keperdataan dengan bapaknya, maka seorang bapak tidak berkewajiban untuk memberikan biaya pemeliharan dan pendidikan terhadap anak tersebut.

\section{Status anak sah}

Anak sah berbeda dengan anak kandung. Anak sah adalah anak yang lahir dalam perkawinan yang sah. Berbeda dengan anak kandung, anak kandung belum tentu anak sah, seperti anak luar kawin dan anak incest. Menurut Dominikus Rato ${ }^{34}$, anak incest adalah anak yang lahir dari hubungan perkawinan yang dilarang, misalnya lahir karena hubungan seks antara saudara kandung. Anak-anak seperti ini hanya mempunyai hubungan hukum dengan ibunya, artinya ia hanya berhak atas harta benda ibunya. Oleh karena itu begitu penting status hukum perkawinan sepasang orang tua, sebab keabsahan perkawinan itu menjadi dasar hukum bagi legalitas atau keabsahan status hukum seorang anak.

Kedudukan anak sah sangat kuat terhadap harta benda bapak ibunya, tetapi terhadap harta asal bapak ibunya anak sah belum tentu secara otomatis dengan sendiri berhak atas harta pustaka tinggi. Norma hukum adat dimana mereka hidup, tumbuh dan berkembanglah yang menentukan. Atau dengan kata lain, secara teoritis bahwa status hukum seseorang ditentukan oleh status hukum menurut konteks sosial diman hukum itu hidup tumbuh dan berkembang.

Menurut hukum adat akibat yang ditimbulkan terhadap anak sah dari perceraian yaitu anak sah harus tetap mendapatkan kasih sayang dari kedua orang tuanya. Seorang bapak berkewajiban membiyai pemeliharan dan pendidikan anak sah dengan bantuan seorang ibu. Anak sah berhak atas harta benda yang dihasilkan kedua orang tuanya selama perkawinan berlangsung.

\section{Status anak angkat}

Pengangkatan anak sering kali dilatar belakangi untuk memperoleh keturunan. Ada yang berfungsi sebagai pemancing yang dilakukan oleh keluarga yang lama kawin tetapi belum mempunyai anak. Menurut Imam Sudiyat ${ }^{35}$, Anak angkat diartikan sebagai suatu ikatan sosial yang sama dengan ikatan kewangsaan biologis. Anak angkat dalam hukum adat mendapat kedudukan yang hampir sama dengan anak kandung.

Pengambilan anak orang lain yang dipelihara dan diperlakukan dengan baik dengan maksud supaya anak itu menjadi anak dari orang tua angkatnya, dengan demikian anak tersebut baik lahir maupun batin dianggap sebagai anaknya sendiri. Orang tua yang mengangkat anak dan anak yang diangkat itu timbul suatu hubungan

\footnotetext{
34 Ibid hlm. 143.

35 Iman Sudiyat, Hukum adat: sketsa asas, cet. ke-2 edition ed (Liberty, 1981) hlm. 12.
} 
kekeluargaan yang sama, seperti yang ada antara orangtua dengan anak kandung sendiri. Anak angkat dalam hukum adat mendapat kedudukan yang hampir sama dengan anak kandung. Menurut Dominikus Rato ${ }^{36}$, anak angkat adalah anak orang lain yang diambil dan dijadikan seperti anak kandung sendiri. Kedudukan anak angkat dibeberapa lingkungan hukum adat tidak sama.

Di dalam masyarakat yang susunannya berbentuk parental seperti di Jawa Tengah dan Jawa Barat dengan masyarakat hukum adat yang susunannya berbentuk patriarchat seperti Bali, kedudukan anak angkat berbeda. Pada masyrakat Osing di Banyuwangi pengangkatan anak dilakukan secara hukum adat, yaitu dilakukan dihadapan anggota keluarga dan tokoh masyarakat agar supaya terang. Ada data yang sangat merarik, yaitu pengangkatan anak oleh ibu tiri terhadap anak hasil zinah suaminya sendiri, sekalipun si ibu itu sudah mempunyai anak kandung. Motifnya adalah keselamatan dan keamanan keluarga.

Menurut hukum adat akibat yang ditimbulkan terhadap anak angkat dari perceraian yaitu anak angkat tetap harus mendapatkan kasih sayang dari kedua orang tuanya angkatnya. Seorang bapak angkat berkewajiban membiyai pemeliharan dan pendidikan anak angkatnya. Anak angkat tidak berhak atas harta benda yang dihasilkan kedua orang tuanya angkatnya.

\section{Status anak tiri}

Pada masyarakat Osing di Banyuwangi juga dikenal adanya anak tiri sebagai hasil perkawinan sebelumnya yang dibawa masuk ke dalam perkawinannya yang kemudian. Hubungan antara anak tiri dengan orangtua tirinya tidak ada bedanya dengan hubungan antara anak kandung dengan orangtua kandungnya. Orangtua tiri berkewajiban untuk merawat, mendidik dan memenuhi semua kebutuhan anak tirinya sampai dewasa. Begitupun sebaliknya, anak tiri mempunyai kewajiban untuk menghormati dan merawat orangtua tirinya sesuai dengan kemampuannya. Menurut dominikus Rato ${ }^{37}$, anak tiri jika tidak diangkat anak oleh ayah atau ibu tirinya, maka ia hanya berhak terhadap harta asal ayah atau ibu kandungnya. Sedangkan terhadap harta gono gini, ia hanya berhak terhadap harta gono gini orang tuanya sendiri.

Anak tiri hanya berhak ats harta benda orang tuanya yang sah secara hukum. Terhadap harta benda orang tua tiri, si anak tidak berhak. Untuk menjaga agar tidak terjadi kerancuan, maka orang tua wajib membagi dan mengklasifikasikan harta benda itu, misalnya harta gono gini perkawinan pertama, kedua dan seterusnya. Anak tiri yang hidup bersama dalam satu rumah dengan ayahnya sendiri bersama ibu tiri atau sebaliknya, adalah warga sekeluarga atau serumah tangga. Terhadap bapak atau ibu kandungnya, anak tersebut berhak atas harta benda orang tuanya. Tetapi terhadap ayah atau ibu tirinya, anak tiri tersebut tidak berhak atas harta benda orang tua tirinya.

Menurut hukum adat akibat hukum yang ditimbulkan terhadap anak tiri dari perceraian yaitu anak tiri tetap ikut dengan orang tua kandungnya, biaya pemeliharan

\footnotetext{
36 Rato, supra note $2 \mathrm{hlm} .157$.

37 Ibid hlm. 164.
} 
dan pendidikan yang menanggung orang tua kandungnya. Anak tiri hanya berhak atas harta benda orang tua kandungnya. Anak tiri tidak memiliki ikatan keperdataan dengan orang tua tirinya, maka orang tua tiri tidak berkewajiban untuk memberikan biaya pemeliharan dan pendidikan terhadap anak tersebut.

\section{B. Status Harta}

Harta merupakan barang yang menjadi kekayaan baik berwujud maupun tidak berwujud yang mempunyai nilai ekonomis atau mempunyai nominal. Masyarakat Osing merupakan masyarakat yang sangat rajin bekerja dan gemar mengumpulkan harta benda terutama berupa tanah. Oleh sebab itu orang Osing memiliki tanah yang terletak tidak hanya di desanya sendiri, tetapi sampai ada yang terletak di desa tetangga. Prinsip orang Osing adalah jika harta benda yang telah didapat sejauh mungkin tidak akan dilepaskan kepada orang lain. Jadi tidak mengherankan jika harta tanah di satu desa dengan harga tanah di desa lain harganya sangat jauh berbeda.

Menurut Dominikus Rato ${ }^{38}$, klasifikasi dan kategorisasi harta benda menurut hukum adat Osing berbeda dengan pembagian menurut hukum adat Jawa. Pada masyarakat Osing dari kalangan normatif dikenal ada 3 macam harta perkawinan yaitu; a) harta asal, yang dibagi lagi atas dua yaitu tanah lanang dan tanah wadon; b) harta gono gini atau harta bersama suami isteri; c) harta pemberian atau hadiah karena balas jasa, seperti tirka mayit. Sedangkan pada masyarakat Osing dari kalangan kaum nominal harta perkawinan itu dibagi menjadi 4 macam yaitu; a) harta asal, harta yang dibagi lagi atas dua yaitu tanah lanang dan tanah wadon; b) harta gono gini; c) harta yang diperoleh suami atau isteri sebelum perkawinan sebagai hasil keringat sendiri; d) pemberian atau hadiah. Secara umum hukum adat Osing, harta benda perkawinan dibagi atas dua yaitu harta asal dan harta gono gini.

\section{Status harta asal}

Harta bawaan atau harta asal merupakan harta yang diperoleh suami isteri sebelum perkawinan. Harta bawaan dibedakan menjadi, harta peninggalan, harta warisan, harta wasiat dan harta hibah. Harta seperti ini disebut pimbit (Ngaju-Dayak), silsila (Makasar), babaktan (Bali), pusaka (Jawa). ${ }^{39}$ Menurut Dominikus Rato ${ }^{40}$, pada masyarakat Osing harta asal dibagi atas harta asal lanang (laki-laki atau suami) dan harta asal wadon (perempuan atau isteri). Harta asal lanang adalah harta benda yang dibawa oleh suami ke dalam perkawinan. Harta asal lanang ini berasal dari harta asal ayahnya yang diterimanya secara turun-temurun dari bapak, kakek, dan seterusnya ke atas menurut garis laki-laki. Harta asal wadon adalah harta yag berasal dari ibunya yang diterimanya dari ibu, nenek dan seterusnya keatas menurut garis perempuan. Menurut pandangan masyarakat Osing yang tidak berpegang teguh pada norma, aturan dan

\footnotetext{
38 Ibid hlm. 77.

39 Hadikusuma (Haji), supra note 15 hlm. 132.

40 Rato, supra note 2 hlm. 78.
} 
ketentuan yang berlaku (kaum nominal), bahwa harta asal lanang dapat berbentuk tanah yang disebut tanah lanang, dapat berwujud tanah sawah, tegalan, pekarangan, pohon-pohon, atau tanaman. Selain tanah, yang wajib dibawa oleh suami adalah meja, kursi, sapi, dan tempat tidur. Barang-barang ini, jika kelak terjadi perceraian tanpa anak, maka harta benda asal lanang ini harus kembali ke kerabat suami. Harta asal wadon dapat berbentuk tanah yang disebut tanah wadon, dapat berwujud tanah sawah, tegalan, pekarangan, pohon-pohon, atau tanaman. Selain tanah, yang wajib dibawa oleh isteri adalah perkakas dapur, kasur, dan lemari. Barang-barang ini, jika kelak terjadi perceraian tanpa anak maka harta benda asal wadon ini harus dikembalikan ke kerabat isteri. Dengan demikian, asas hukum bahwa harta asal kembali ke asal sangat ditaati, diterapkan secara konsisten, jadi tidak hanya secara normatif saja. Harta asal yang dibagi lagi atas tanah lanang tanah wadon.

Pada masyarakat Osing prinsip harta asal kembali ke asal sudah sangat membumi. Tanah lanang adalah tanah atau harta benda yang dibawa atau diperoleh suami dari orang tuanya. Apabila terjadi suatu perceraian maka tanah ini menjadi hak suami. Tanah wadon merupakan tanah atau harta benda yang dibawa atau diperoleh isteri dari orang tuanya. Apabila terjadi suatu perceraian maka harta benda wadon menjadi hak isteri. Pada prinsipnya harta asal harus kembali ke asal.

\section{Status harta gono gini}

Harta gono gini atau harta bersama secara etimologi adalah dua kosakata yang terdiri dari kata harta dan kata bersama. Dalam Kamus Besar Bahasa Indonesia, harta adalah barang-barang (uang dan sebagainya) yang menjadi kekayaan, harta bisa diartikan juga sebagai kekayaan berwujud dan tidak berwujud yang bernilai. Jadi harta bersama adalah harta yang diperoleh secara bersama didalam perkawinan. ${ }^{41}$

Secara terminologi, harta bersama adalah harta yang diperoleh bersama suami isteri selama perkawinan. Di Jawa, harta bersama disebut dengan istilah "gono gini", di Sunda disebut "guna kaya", di Bugis disebut "cakara" atau "bali reso", dan di Banjar disebut "harta berpantangan". ${ }^{42}$ Pada tiap-tiap daerah masyarakat mengenal harta bersama dengan istilah berbeda, namun pada hakikatnya adalah sama. Menurut Dominikus Rato ${ }^{43}$, harta gono gini diperoleh melalui campur kaya antara harta yang dibawa suami (tanah lanang) dan harta yang dibawa oleh isteri (tanah wadon).

Harta gono gini menjadi hak bersama suami isteri walaupun yang mengelola hanya suami, tetapi peran isteri yang mengurus rumah tangga dan anak di rumah cukup berarti dalam pembentukan hart gono gini. Apalagi isteri yang hidupnya sederhana dan mampu mengelola harta benda yang dihasilkan oleh suami. Oleh karena itu, harta gono gini menjadi hak bersama.

41 Pusat Pembinaan dan Pengembangan Bahasa (Indonesia), Kamus besar bahasa Indonesia / tim penyusun kamus, Pusat Pembinaan dan Pengembangan Bahasa (Jakarta: Departemen Pendidikan dan Kebudayaan: Balai Pustaka, 1989) hlm. 299.

42 Hamzah, supra note 29 hlm. 232.

43 Rato, supra note 2 hlm. 84. 
Di Desa Aliyan besar bagian harta gono gini akibat perceraian yang diterima oleh suami isteri masing-masing mendapatkan seperdua dari harta gono gini, yang dilakukan dengan cara musyawarah oleh keluarga besar para pihak ${ }^{44}$ didampingi oleh tokoh masyarakat. Selanjutnya kedudukan anak kandung, anak sah, anak angkat dan anak tiri adalah sama. Orang tua biasanya tidak pernah membeda-bedakan anak kandung, anak sah, anak angkat dan anak tiri. Orang tua akan menganggap anak kandung, anak sah, anak angkat dan anak tiri tersebut sebagai anak sendiri. ${ }^{45}$

Sehubungan dengan uraian diatas dapat disimpulkan bahwa penelitian di Desa Aliyan, Kecamatan Rogojampi, Kabupaten Banyuwangi, mengenai status hukum anak akibat perceraian masyarakat adat Osing tidak pernah membedakan antara anak kandung, anak sah, anak angkat dan anak tiri, kedudukan anak-anak tersebut adalah sama. Anak-anak tersebut tetap mendapatkan kasih sayang dan biaya pendidikan dari orang tuanya meskipun orang tuanya telah bercerai. Mengenai status hukum harta benda akibat percerain, harta asal akan kembali ke asal, maksudnya tanah lanang menjadi hak suami dan tanah wadon menjadi hak isteri. Sedangkan harta gono gini akan dibagi sama rata, karena menurut hukum adat Osing kedudukan suami isteri sejajar.

\section{KESIMPULAN}

Menurut masyarakat Osing di Desa Aliyan, perceraian adalah kembalinya wong lanang (suami) dan wong wadon (isteri) tersebut kedalam kelompok kerabatannya sendiri. Kembalinya wong lanang (suami) dan wong wadon (isteri) ke kerabat masing-masing akan menimbulkan hak dan kewajiban terhadap anak dan harta benda yaitu harta gono gini. Akibat hukum dari percerian terhadap anak di Desa Aliyan yaitu tetap melekatnya hak seorang anak untuk memperoleh perlindungan dan kasih sayang dari orang tuanya yang bercerai. Bapak bertanggung jawab atas semua biaya pemeliharaan dan pendidikan anak, apabila bapak tidak mampu maka seorang ibu harus ikut memikulnya. Akibat hukum dari perceraian terhadap harta bersama di desa Aliyan, suami dan isteri yang telah bercerai berhak atas harta bersama atau harta gono gini yang dihasilkan selama perkawinan berlangsung, tanpa melihat prestasi pihak mana yang bekerja keras. Pembagian harta bersama didasarkan pada hidup bersama selama perkawinan dan dibagi sama rata sesuai dengan keputusan hasil musyawarah kedua pihak keluarga. Status hukum anak kandung, anak sah, anak angkat dan anak tiri menurut hukum adat Osing di Desa Aliyan adalah sama.

Masyarakat adat Osing di Desa Aliyan tidak pernah membedakan antara anak kandung, anak sah, anak angkat dan anak tiri. Anak-anak tersebut tetap mendapatkan kasih sayang dan biaya pendidikan dari orang tuanya meskipun orang tuanya telah bercerai. Mengenai status hukum harta benda akibat percerain, harta asal akan kembali

44 Anton Sujarwo, Hasil wawancara dengan Bapak Anton Sujarwo S.E sebagai Kaur Umum Desa Aliyan, Kecamatan Rogojampi, Kabupaten Banyuwangi (2017).

45 Bambang Supinto, Hasil wawancara dengan Bapak Bapak Bambang Supinto Hadi sebagai Kasi Pembangunan Desa Aliyan, Kecamatan Rogojampi, Kabupaten Banyuwangi (2017). 
ke asal, maksudnya harta bawaan suami menjadi hak suami dan harta bawaan isteri menjadi hak isteri. Sedangkan harta gono gini akan dibagi sama rata, karena menurut hukum adat Osing kedudukan suami isteri sejajar. Hendaknya masyarakat Osing di Desa Aliyan tetap mempertahankan suatu perkawinan dan meminimalkan angka perceraian, karena perceraian dapat menimbulkan masalah baru terhadap anak dan harta perkawinan.

Mengenai akibat hukum terhadap harta bersama dari perceraian di desa Aliyan, hendaknya masyarakat desa Aliyan tetap mempertahankan cara adat dalam pembagian harta bersama dari suatu perceraian, dimana suami dan isteri mendapatkan bagian yang sama rata untuk menghindari perselisihan. Hendaknya masyarakat adat Osing di Desa Aliyan tetap mempertahankan hukum adat yang tidak pernah membedakan mengenai kedudukan anak kandung, anak sah, anak angkat dan anak tiri. Anak-anak tersebut tetap mendapatkan kasih sayang dan biaya pendidikan dari orang tuanya meskipun orang tuanya telah bercerai. Mengenai status harta perkawinan akibat perceraian sebaiknya masyarakat adat Osing tetap mempertahankan hukum adat, dimana harta asal akan kembali ke asal, maksudnya harta bawaan suami menjadi hak suami dan harta bawaan isteri menjadi hak isteri. Sedangkan harta gono gini akan dibagi sama rata, karena menurut hukum adat Osing kedudukan suami isteri sejajar.

\section{DAFTAR PUSTAKA}

Andi Hamzah, Kamus hukum, cet. 1 edition ed (Jakarta: Ghalia Indonesia, 1986).

Bambang Daru Nugroho, Asas-asas e tatanan hukum adat (Mandar Maju, 2011).

Dominikus Rato, Hukum Perkawinan dan Waris Adat: Sistem Kekerabatan, Bentuk Perkawinan dan Pola Pewarisan Adat Di Indonesia (Surabaya: Laksbang Yustisia Surabaya, 2011).

Hasil wawancara dan kesaksian Bapak Ishak Maulana, Ibu Lisudalmi dan Ibu Suwati (2017).

Hilman Hadikusuma (Haji), Hukum perkawinan adat (Citra Aditya Bakti, 2003).

Iman Sudiyat, Hukum adat: sketsa asas, cet. ke-2 edition ed (Liberty, 1981).

J.C.T. Simorangkir, Kamus hukum: oleh J. C. T. Simorangkir, Rudy T. Erwin dan J. T. Prasetyo (Madjapahit, 1972).

Nur Ainiyah, "Islam Osing dalam Bingkai Tradisi dan Kosmologi: Studi Nelayan Kedungrejo-Banyuwangi”, online: 〈http:// ejournal.kopertais4.or.id/tapalkuda/ index.php/lisan/article/view/2841/2095>.

Otje Salman, Rekonseptualisasi hukum adat kontemporer: telaah kritis terhadap hukum adat sebagai hukum yang hidup dalam masyarakat, Telaah kritis terhadap hukum adat sebagai hukum yang hidup dalam masyarakat (Bandung: Alumni, 2002).

Paturi. Hasil wawancara dengan Bapak Paturi sebagai Sekretaris Desa Aliyan, Kecamatan Rogojampi, Kabupaten Banyuwangi (2017).

Pusat Pembinaan dan Pengembangan Bahasa (Indonesia). Kamus besar bahasa Indonesia / tim penyusun kamus, Pusat Pembinaan dan Pengembangan Bahasa (Jakarta: Departemen Pendidikan dan Kebudayaan : Balai Pustaka, 1989). 
244 | Perceraian dan Akibat Hukumnya terhadap Anak dan Harta Bersama Menurut Hukum Adat Osing ...

Sarifudin. Hasil wawancara dengan Bapak Sarifudin sebagai Tokoh Masyarakat Desa Aliyan, Kecamatan Rogojampi, Kabupaten Banyuwangi (2017).

Subekti, Pokok-pokok hukum perdata (P.T. Intermasa, 1978).

Sujarwo, Anton. Hasil wawancara dengan Bapak Anton Sujarwo S.E sebagai Kaur Umum Desa Aliyan, Kecamatan Rogojampi, Kabupaten Banyuwangi (2017).

Sulistyowati Irianto, Pluralisme hukum waris dan keadilan perempuan / Sulistyowati Irianto (Jakarta: Yayasan Pustaka Obor Indonesia, 2016).

Sulistyowati Mahdi \& dkk. Hukum Perdata: Suatu Pengantar (Jakarta: Gitama Jaya Jakarta, 2005).

Supinto, Bambang. Hasil wawancara dengan Bapak Bapak Bambang Supinto Hadi sebagai Kasi Pembangunan Desa Aliyan, Kecamatan Rogojampi, Kabupaten Banyuwangi (2017).

Suwati. Hasil wawancara dengan Ibu Suwati sebagai masyarakat yang pernah melakukan perceraian di Desa Aliyan, Kecamatan Rogojampi, Kabupaten Banyuwangi (2017).

Wirjono Prodjodikoro, Hukum perkawinan di Indonesia (Sumur Bandung, 1966). 